\title{
THE ROCHELONGUE UNDERWATER SITE AND THE COASTAL MOBILITY IN WEST LANGUEDOC (FRANCE) DURING THE TRANSIT FROM LATE BRONZE AGE TO EARLY IRON AGE
}

\author{
EL YACIMIENTO SUBMARINO DE ROCHELONGUE Y LA \\ MOVILIDAD COSTERA EN LANGUEDOC OCCIDENTAL \\ (FRANCIA) DURANTE EL TRÁNSITO DE LA EDAD DEL BRONCE \\ TARDÍA A LOS INICIOS DE LA EDAD DEL HIERRO
}

\author{
ENRIQUE ARAGÓN NÚÑEZ \\ enrique.aragon@,flinders.edu.au \\ Flinders University 1 \\ [RECIBIDO 10/03/2020; ACEPTADO 26/05/2020] \\ http://doi.org/10.25267/Riparia.2020.v6.01
}

\begin{abstract}
This paper examines the material culture of the Rochelongue underwater site by providing key information to better understand traditional discussions about the site, such as its chronology, cultural attribution and nature. This paper, however, focuses on the concept of coastal mobility as an approach that provides access to a much broader assessment of the local population in terms of maritime cultural contact. Maritime interactions are vital in order to understand socioeconomic changes and processes in culture contact and colonial settings in western Languedoc, which occurred during the seventh and sixth centuries B.C. The direct network that shows the Rochelongue underwater site by studying the distribution of metallic objects from the assemblage allows the discussion about the necessity of further investigation in the analysis of local coastal mobility to better understand connectivity and cultural encounters during Late Bronze Age-Early Iron Age in Western Mediterranean.
\end{abstract}

KEY WORDS: Mobility, maritime connectivity, underwater archaeology, shipwreck, cultural contact, coastal archaeology, seascape.

1 Flinders University. Departament of Archaeology / Universidad de Cádiz. Departamento de Historia, Geografía y Filosofía.

E. Aragón Núñez, "The Rochelongue underwater site and the coastal mobility in West Languedoc (France) during the transit from Late Bronze Age to Early Iron Age”, RIP ARIA 6 (2020), 1-29 


\section{RESUMEN}

Este artículo examina la cultura material asociada al yacimiento subacuático de Rochelongue aportando información relevante para entender mejor la discusión tradicional existente sobre la cronología, la adscripción cultural y la propia naturaleza del yacimiento. Este articulo, sin embargo, se centra en una nueva perspectiva interpretativa, utilizando el concepto de movilidad costera como contexto que nos ayuda a realizar un examen mucho más amplio de la relevancia del yacimiento y la población local en términos de contactos culturales. Las interacciones marítimas asociadas al yacimiento son claves para entender los cambios socioeconómicos y los encuentros entre las poblaciones del Oeste del Languedoc, en un contexto de inicio de la presencia de culturas mediterráneas (griegos, fenicios y etruscos) en la costa del Sur de Francia, que se produce durante los siglos séptimo y sexto a.C. Las redes que se identifican en torno al yacimiento de Rochelongue en base a la distribución de su cargamento de objetos metálicos, permite abrir una discusión en la necesidad de ampliar los estudios sobre las capacidades de la movilidad costera de poblaciones indígenas durante el proceso de colonización, para un mejor entendimiento de la conectividad y los encuentros culturales sucedidos entre el Bronce final y el Hierro I en el Mediterráneo Occidental.

Palabras ClAVE: Movilidad, conectividad marítima, arqueología subacuática, pecio, interacción cultural, arqueología costera.

"The Rochelongue underwater site and the coastal..." 


\section{Introduction: mobility as phenomena.}

Prior to the 1980s, mobility was rarely used as a broad theoretical construct for studying Mediterranean immigration (colonisation), cultural encounters and their social ramifications ${ }^{2}$. Although research was indicating that the movement of populations in the Bronze Age was important and relevant to understanding processes, such as Greek expansion ${ }^{3}$, mobility was treated merely as long-distance movement rather than as a socially structured phenomenon ${ }^{4}$. In recent decades, however, the question of mobility of individuals in ancient societies has received greater attention. Osborne ${ }^{5}$, for example, has stressed the need to study its forms and causes, and warns that historians of antiquity should not underestimate the degree of mobility of ancient populations. He also emphasised the relative character of distance in the study of migratory phenomena. It is important, therefore, to take into account how past populations conceived of space and not just distance in an absolute sense ${ }^{6}$.

Thus, mobility may be conceived as the mechanism that produces a degree of connectivity, which, using Horden and Purcell's ${ }^{7}$ approach, is the various ways in which 'micro-regions cohere, both internally and also one with another'. More broadly, connectivity is the mobility of people and goods, the means of

2 M.I. FInLEY, The ancient economy, University of California Press, Los Angeles 1973; P. VAN DOMmelen, "Colonialism and Migration in the Ancient Mediterranean", Annual Review of Anthropology 41, 2012, 393-409.

3 J.P. Morel, "Les relations économiques dans l'Occident grec", Publications de l'École française de Rome 67/1, 1983, 549-580.

${ }^{4}$ C. MOAтTI, "Mobilités et circulations: approches historiographique et conceptuelle", Mobilités grecques. Mouvements, réseaux, contacts en Méditerranée, de l'époque archaïque à l'époque bellénistique 46, 2012, 40.

5 R. OsBorne, "The potential mobility of human populations", Oxford Journal of Archaeology 10/2, 1991, 231-252.

${ }^{6}$ C. Moatti, "Mobilités et circulations...", 41.

7 P. Horden, N. Purcell The corrupting sea: a study of Mediterranean history, WileyBlackwell, Oxford,2000, 123. 
travel and communication and any resultant social exchange ${ }^{8}$. From the perspective of western Mediterranean encounters, chain migration (chain mobility) — communities migrating one after another over an extended period of time and settling down together- is an important mechanism for the creation of patterns of connectivity that directly affect the region of settlement ${ }^{9}$. Socially, material culture allows us to explore the relationship between mobility patterns and contact situations. Material culture, or materiality, can help us address the diversity and scale of mobility and connectivity between micro-regions in coastal Languedoc (Figure 1) by examining imports (what was imported and from where), imitations (as indicators of value and meaning) and numbers of such (as indicators of intensity of interaction $)^{10}$. Connectivity and mobility also are pertinent to discussions concerning maritime contexts and have been used to create a theoretical framework for investigating past Mediterranean societies and the formation of identity through subsequent cultural interactions ${ }^{11}$. Following this, maritime connectivity (via merchants, mariners and local traders) determines the level of relationship between different coastal or island communities, as well as the intensity of these connections $^{12}$. Within the context of this paper, mobility can be understand as maritime transhumance ${ }^{13}$, which constantly

8 A.B. KNAPP, S. DemeSTICHA, Mediterranean connections: maritime transport containers and seaborne trade in the Bronze and Early Iron Age, Taylor \& Francis, New York 2016, 30.

9 P. VAn Dommelen, “Colonialism and Migration...", 404.

10 J. VIVES-FERRÁNDIZ, "Mediterranean Networks and material connections: a view from eastern Iberia and The Balearic Islands (12th-8th Centuries BC)", A. BABBI (ed.), The Mediterranean Mirror: Cultural Contacts in the Mediterranean Sea Between 1200 and 750 BC. Schnell \& Steiner GmbH., Verlag des Römisch-Germanischen Zentralmuseums, Mainz 2015, 161-175.

11 J. LEIDWANGER, "Modeling distance with time in ancient Mediterranean seafaring: a GIS application for the interpretation of maritime connectivity", Journal of Archaeological Science 40/8, 2013, 3302.

12 A.B. Knapp, S. Demesticha, Mediterranean connections...”, 30.

13 M. Gras, "Avant les réseaux. Les stratigraphies conceptuelles de la Méditerranée archaïque”, L. Capdetrey, J. Zurbach (eds), Mobilités grecques. Mouvements, réseaux,

"The Rochelongue underwater site and the coastal..." 
disrupts the stability of locals, combining elements of sedentary life with phases of mobility. Studies of the Rochelongue site traditionally have focused on the chronologies and cultural attributes of the remains, as well as the question of what type of site it represents-shipwreck or ritual deposit ${ }^{14}$. As yet, there is no general consensus on these issues. Rather than focusing on site characterisation, which would need a more extensive study ${ }^{15}$. This paper introduces a new approach into the Rochelongue metallic finds, using them as an evidence of coastal mobility.

\section{Societies moving to the coast.}

It is difficult to understand the Late Bronze Age (LBA)Early Iron Age (EIA) transition for west Languedoc (France) in terms of population and dispersion due to the scarcity of information. The socio-economical model traditionally applied to the LBA in southwestern France is one of agro-pastoral subsistence augmented with partial exploitation of coastal resources ${ }^{16}$. Settlements are dispersed and are occupied during short and variable episodes. This semi-nomadic model reveals a tribal characteristic that contrasts with an emerging new structure in the EIA, where greater social hierarchy develops with the

contacts en Méditerranée, de l'époque archaïque à l'époque hellénistique, De Boccard, Bourdeaux 2012, 21.

14 A. Barbot, Les Épaves Archäques...; J. Gasco, C. Tourette, G. Borja, “À propos du dépôt de bronze launacien de Rochelongue (Agde, Hérault)", Documents d'archéologie méridionale. Protohistoire du Sud de la France 35, 2014, pp. 207-228; L. LONG, Les épaves protohistoriques de la côte gauloise et de la Corse:(Vle-IIIe siècles avant J.C.). La circulació d'àmfores al Mediterrani occidental durant la Protohistòria (segles VIII-III $a C$ ): aspectes quantitatius $i$ anàlisi de continguts, Departament de Prehistòria, Història Antiga i Arqueologia, Calafell 2004; L. Long, P. Pomey, J.-C. Sourisseau, Les Étrusques en mer: épaves d'Antibes à Marseille, Édisud, Marseille 2002; C. Hugues, "La découverte sous-marine de Rochelongue, Agde (Hérault)", Comptes-rendus des séances de l'année. Académie des inscriptions et belles-lettres 109/1, 1965, 176-178.

15 This underwater site its subject of study of the author dissertation submitted in February 2020, that offer an insight analysis of the assemblage.

16 D. Garcia, La Celtique méditerranéenne: Habitats et sociétés en Languedoc et en Provence du VIIIe au IIe siècle avant JC., Editions Errance, Paris 2004; M. PY, Les gaulois du Midi. De la fin de l'âge du Bronz̧e à la conquête romaine, la memoire du temps, Hachette, Paris 1993. 
appearance of 'big men'17. On the other hand, the model is at odds with certain settlements of the LBA that show signs of proto-urbanisation. Sites such as Ruscino, Carsac and Mailhac in Roussillon and west Languedoc, or Sextantio, Roque-de-Viou and Le Marduel in east Languedoc, led Eric Gailledrat ${ }^{18}$ to argue that the semi-nomadic model of local societies is not functional. Gailledrat ${ }^{19}$, on the other hand, argues for consideration of some kind of previous social structure where the aristocracy already were present, only not as evident as in later periods.

17 D. GARCIA, La Celtique méditerranéenne..., 49.

18 E. Gailledrat, "Tierra, fuego y agua: poder y sociedad entre el Ródano y los Pirineos durante la primera Edad del Hierro", M.C. BELARTE, D. GARCiA, J. SANMARTí (eds.), Les estructures socials protohistóriques a la Gällia $i$ a Ibèria, Calafell: Arqueo Mediterrania, 2013, 106.

19 E. GAILLEDRAT, “Tierra, fuego y agua... ”, 106.

"The Rochelongue underwater site and the coastal..." 


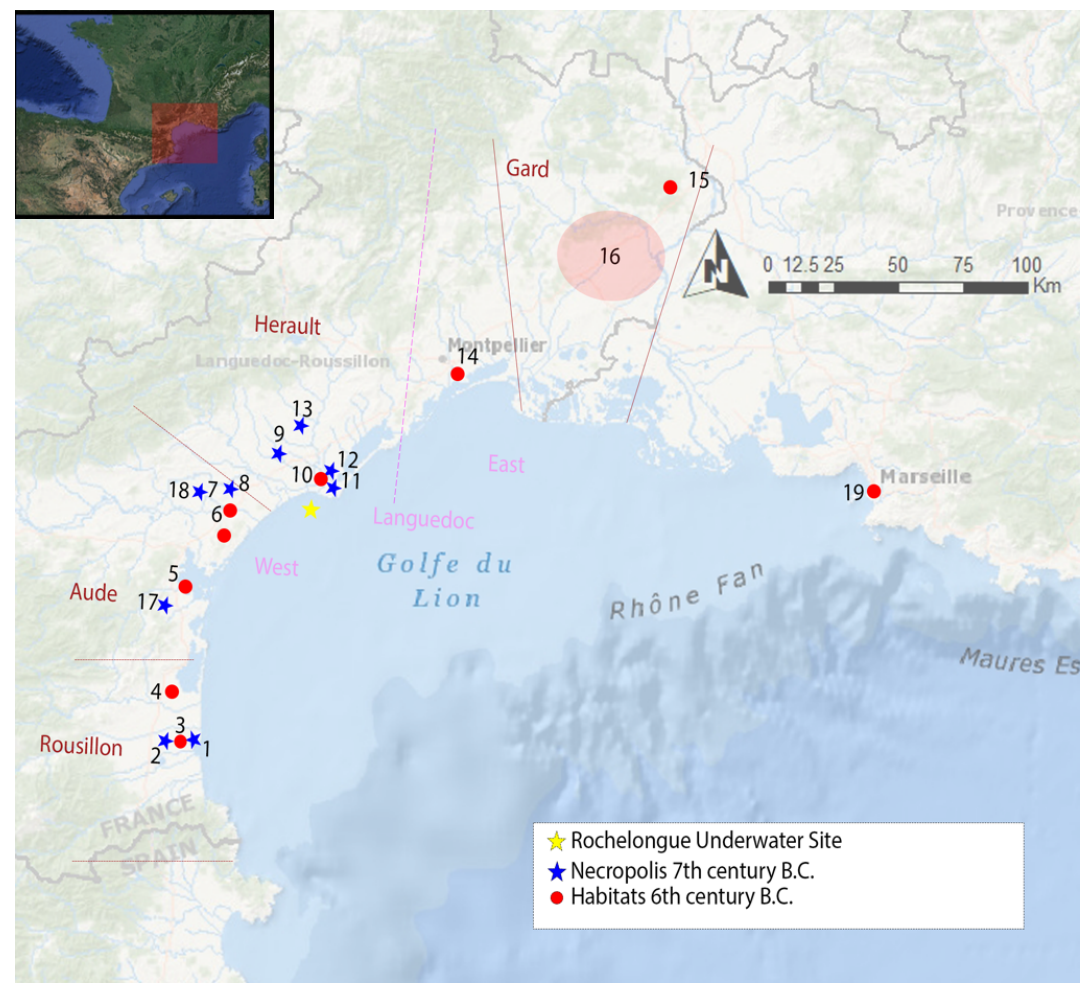

Figure 1. Map of coastal Languedoc-Roussillon showing sites and areas mentioned in the text and the division between east and west Languedoc (pink dashed line) (after Ugolini 2018:232 fig. 1): 1. Necropolis de Bellevue (Canet, Pyrénées-Orientales); 2. Necropolis de Négabous (Perpignan, Pyrénées-Orientales); 3. Ruscino (ChâteauRoussilon, Pyrénées-Orientales); 4. Le Port 2 (Salses-le-Château, Pyrénées-Orientales); 5. Pech Maho (Sigean, Aude); 6. Montlaurès (Narbonne, Aude); 7. Cayla II (Mailhac, Aude); 8. Necropolis du Grand Bassin I (Mailhac, Aude); 9. Necropolis de La Courondelle (Béziers, Hérault); 10. La Monédière (Bessan, Hérault); 11. Necropolis du Peyrou (Agde, Hérault); 12. Necropolis du Bousquet (Agde, Hérault); 13. Necropolis de La Cartoule (Servian, Hérault); 14. Lattes (Hérault);15. Grotte Suspendue (Collias, Sainte-Anastasie, Gard); 16. Région nîmoise (Gard); 17. Necropolis de L'Agrédo (Roquefort-Corbières, Aude); 18. Grotte de Buffens (Caunes-Minervois, Aude). 
In the specific case of the Hérault Basin, the formation of settlements is not well known, especially during the LBA. The short list of Bronze Age coastal habitation sites in the area include La Motte, at the mouth of the Hérault River ${ }^{20}$, and La Fangade, by Lake Thau ${ }^{21}$, which were characterised by piledwellings. During the transition from the LBA to the EIA, there is a reported increase in the number of $\operatorname{sites}^{22}$, most being located in the southern part of the Hérault basin ${ }^{23}$. In the seventh century B.C., the main development is the occupation of the lower coastal plain, although this is evidenced more by necropoleis than by actual habitation sites ${ }^{24}$. The two most important necropoleis were Peyrou, in $\mathrm{Agde}^{25}$, and Saint-Julien, in Pezenas $^{26}$, and together they represent the stability of settlements in the Hérault Valley. Recent reconstructions of the paleolandscape of this area are revealing that it was much more inundated than it is now ${ }^{27}$. During the LBA-EIA, the present

20 P.A. Moyat, Dumont, J.-F. Mariotti, T. Janin, S. Greck, L. Bouby, P. Ponel, P. VERDIN, S. VERGER, "Découverte d'un habitat et d'un dépôt métallique non funéraire du VIIIe s. av. J.-C. dans le lit de l'Hérault à Agde, sur le site de La Motte", Jabrbuch des Römisch-Germanischen Zentralmuseums Mainz 54/1, 2010, 53-84.

${ }^{21}$ F. Leroy, L. Bouby, F. GuiBAL, Les gisements protohistoriques de l'étang de Thau (Hérault). Temps et espaces culturels du VTe au IIe millénaire en France du Sud, IVe Rencontres Méridionales de Préhistoire Récente, Association pour le développement de l'archeologie en Languedoc-Rousillon, Nîmes 2000.

22 E. GAILLEDRAT, Espaces coloniaux et indigènes sur les rivages d'Extrême-Occident méditerranéen (Xe-IIle s. avant notre ère), Pulm, Montpellier 2014.

23 V. Ropiot, Peuplement et circulation dans les bassins fluviaux du Languedoc occidental, $d u$ Roussillon et de l'Ampourdan du IXe s. au début du IIe s. av. n. è, Université de FrancheComté, Besançon 2007, 150.

24 E. Gailledrat, Espaces coloniaux et...

25 A. Nickels, G. Marchand, M. Schwaller, H. Duday, P. Columeau, "Agde, la nécropole du premier Âge du Fer”, Revue Archéologique de Narbonnaise. Suppléments 19, 1980, 1-499.

26 J. GIRY, "La nécropole préromaine de St-Julien (Cne de Pézenas, Hérault)", Rivista di Studi Liguri 31, 1965, 117-235; C. LlinAS, A. ROBERT, "La nécropole de Saint-Julien à Pézenas. Fouilles 1969-1970", Revue archéologique de Narbonnaise 4/1, 1971, 1-29; A. NiCKELS, "Essai sur le développement topographique de la nécropole protohistorique de Pézenas (Hérault)", Gallia 47, 1990, 1-27.

27 B. Devillers, G. Bony, J.-P. Degeai, J. Gascó, T. Lachenal, H. Bruneton, F. Yung, H. Oueslati, A. Thierry, "Holocene coastal environmental changes and

"The Rochelongue underwater site and the coastal..." 
mouth of the Hérault River was a paleo-bay, which, along with the river, provided an ideal point of convergence for establishing commercial contacts. This is illustrated by the discovery of vases of Greek and Phoenician manufacture, the oldest of these types in France ${ }^{28}$. Finally, the first half of the sixth century B.C. saw a significant increase in occupation sites with increased density, with a remarkable concentration of population in the low and middle course of the valley. At the end of the EIA, the so-called Oppida appears. These are permanent and sometimes fortified settlements that testify to the stability of some communities and their control of surrounding territory and secondary minor sites $^{29}$.

It is difficult to reconstruct the social organisation of the communities established in the Hérault/Agde territory during this time due to the relatively poor archaeological information available. Burials associated with habitats are homogeneous, suggesting a relatively equal social treatment of individuals at death $^{30}$. Nevertheless, there are some distinctive signs of social complexity, and two types of burials are recognised: circular tombs, representing the majority, and rectangular ones better furnished with artefacts. For male burials, riding equipment and the weapons are identified as symbol of power, whereas female graves of special status may result from the combination of

human occupation of the lower Hérault River, southern France". Quaternary Science Reviews 222/1, 2019, 16.

28 E. Gailledrat, “Tierra, fuego y agua... "; E. Gailledrat, Espaces coloniaux...; D. UGOLINI, L'identité face au commerce: exemples languedociens. Contacts et acculturations en Méditerranée occidentale: hommages à Michel Bats, Éditions Errance, Centre Camille Jullian, Hyères-les-Palmiers 2018.

29 E. Gailledrat, "Tierra, fuego y agua... ", 106; J. GASCO, "Geographie regionale de l'age du bronze en Languedoc", Quaderns de prehistòria i arqueologia de Castelló 29, 2011, 135-151.

30 T. JAnIN, "L'évolution du Bronze final IIIB et la transition Bronze-Fer en Languedoc occidental d'après la culture matérielle des nécropoles", Documents d'archéologie méridionale 15/1, 1992, 243-259; O. TAFFAnEL, J. TAFFAnEL, "Deux tombes de cavaliers du Ier Âge du Fer à Mailhac (Aude)", Gallia 20/1, 1962, 3-32. 
different roles within the society ${ }^{31}$. The group associated with these last burial typologies comprise a small local elite. Differences in the variations of funerary rituals reveal a west Languedoc divided into small tribal entities, which can be subdivided into two large groups. One stretches from Carcassone to the middle valley of the river Orb, and the second is centred around the two necropolises of the Agde region at Peyrou and Bousquet $^{32}$. From the LBA to the EIA, the Languedoc territory experienced a social evolution from more egalitarian societies to the entrenchment of aristocracies. These social elites benefited from the circulation of people and objects, which, throughout the Bronze Age, traditionally was linked to fluvial and terrestrial communication routes to the Atlantic, Iberian Peninsula and northern Italy, and which ultimately accelerated maritime trade with the broader Mediterranean world ${ }^{33}$.

Colonial trade and long-distance exchange relations were cemented at the end of the EIA, with local elites highly influenced by Phoenician, Greek and Etruscan cultural practices. Consequently, these local societies experienced transformations in social hierarchy and the system for controlling and managing material resources. Within the context of this paper, this can be understood as the convergence of symbiotic interests of foreign groups in access to mineral and other natural resources and of local privileged groups in prestige goods that enhance and

31 S. Lenorzer, "Pratiques funéraires du Bronze final IIIb au premier âge du Fer en Languedoc occidental et Midi-Pyrénées: approche archéo-anthropologique des nécropoles à incinération", Bulletin de la Société préhistorique française 103/3, 2006, 622-625.

32 S. Verger, L. Pernet, Une Odyssée gauloise: parures de femmes à l'origine des premiers échanges entre la Grèce et la Gaule, Éditions Errance, Montpellier 2013.

33 D. GARCIA, Entre Ibères et Ligures: Lodévois et moyenne vallée de l'Hérault protobistoriques, CNRS Éditions, Paris 1993; R. GRAELLS, S. SARDA, "Entre carneros, palomas y ciervos: la asimilación de estimulos mediterráneos a través de la Toréutica. El ejemplo del noreste de la Península ibérica durante el s. VI aC.", Rivista di Studi Liguri 71, 2007, 5-28; R. GRAells, Las tumbas con importaciones y la recepción del Mediterráneo en el nordeste de la Peninsula Ibérica (siglos VII-VI a.C), Departamento de Arqueologia, Universitat de Lleida, Lleida 2010; S. Verger, L. Pernet, Une Odyssée gauloise: parures de femmes à l'origine des premiers échanges entre la Grèce et la Gaule, Éditions Errance, Montpellier 2013, 54.

"The Rochelongue underwater site and the coastal..." 
maintain their social distinction. These associations, whereby locals adopt foreign customs that then co-exist with traditional practices, have a complex interpretation. Furthermore, the existence of previous local and long-distance trade circuits and the potential active role of local communities allow for discussion about the nature of these first encounters in what it's been defined by some authors as the liminal zone ${ }^{34}$.

These encounters, however, could not have happened without a conducive social framework ${ }^{35}$. This framework should be understood as the ability of local groups to organise or even guarantee the material conditions for exchange, to engage existing exchange networks and perhaps to mobilise productive forces that, before then, were oriented only to local needs. Taking all of this into account, the phenomenon of 'Launacien' metal hoards is fundamental to identifying the scope of these contacts ${ }^{36}$.

\section{Mobility of metal towards the coast. Launac and the Launacien.}

The French engineer, geologist and anthropologist Paul Cazalis de Fondouce was the first to give the name Launacien to this local metallurgical tradition. In 1897, a group of farmers from Launac, at Fabrègues (Hérault), found a group of bronze objects buried in the ground. The landowner offered the pieces to the Archaeological Society of Montpellier. The entire

\footnotetext{
34 A. Gorgues, "Trade in a liminal zone. Commercial encounter and transformation in the Iron Age North West Mediterranean”, I. Armit, P. Hrvoje, M. Cresnar, P. MASON, L. Büster (eds), Cultural Encounters in Later Prehistoric Europe, Budapest 2016, 167-210.

35 E. Gailledrat, “Tierra, fuego y agua...”, 108; E. GAILlEDrat, Espaces coloniaux... 36 J. Guilaine, L'âge du Bronze en Languedoc occidental, Roussillon, Ariège, Klincksieck, Paris 1972; J. Guilaine, L. Carozza, D. Garcia, J. Gasco, T. Janin, B. Mille, Launac et le Launacien. Dépôts de bronzes protohistoriques du sud de la Gaule, Presses Universitaires de la Méditerranée, Montpellier 2017.
} 
collection was the subject of a publication in 1900 by de Fondouce, who described the discovery as a 'smelting hoard'37.

This assemblage from Launac included socketed axes, triangular scrapers, incised bracelets, and socketed hammers, extending from a long tradition. The Launacien phenomenon is defined by a series of large deposits discovered in the region of Aude and Hérault ${ }^{38}$. Among these deposits, the assemblage recovered from the Rochelongue underwater site, at a depth of 8 $\mathrm{m}$, near Cap d'Agde, is one of the most representative. The assemblage shows a much greater quantity of artefacts (Figure 2) compared to those from terrestrial contexts. The Launac deposit, for instance, contains 678 artefacts, compared to Rochelongue's 4,640 (almost seven times as many). Furthermore, the Rochelongue site is significant because of its large number of copper ingots $^{39}$, including 119 complete ingots, 239 partial ingots and 2,961 fragments of smelted copper.

37 P. Cazalis de Fondouce, "La cachette de fondeur de Launac", Mémoires de la Société Archéologique de Montpellier 2, 1900, 171-172.

38 J. Guilaine, L. Carozza, D. Garcia, J. Gasco, T. Janin, B. Mille, Launac et le Launacien..., 16-17.

39 S. Junghans, E. SAngmeIster, M. SChrö̈ER, Kupfer und Bronze in der fruihen Metallzeit Europas 4, Gebr.Mann, Berlin 1974.

"The Rochelongue underwater site and the coastal..." 


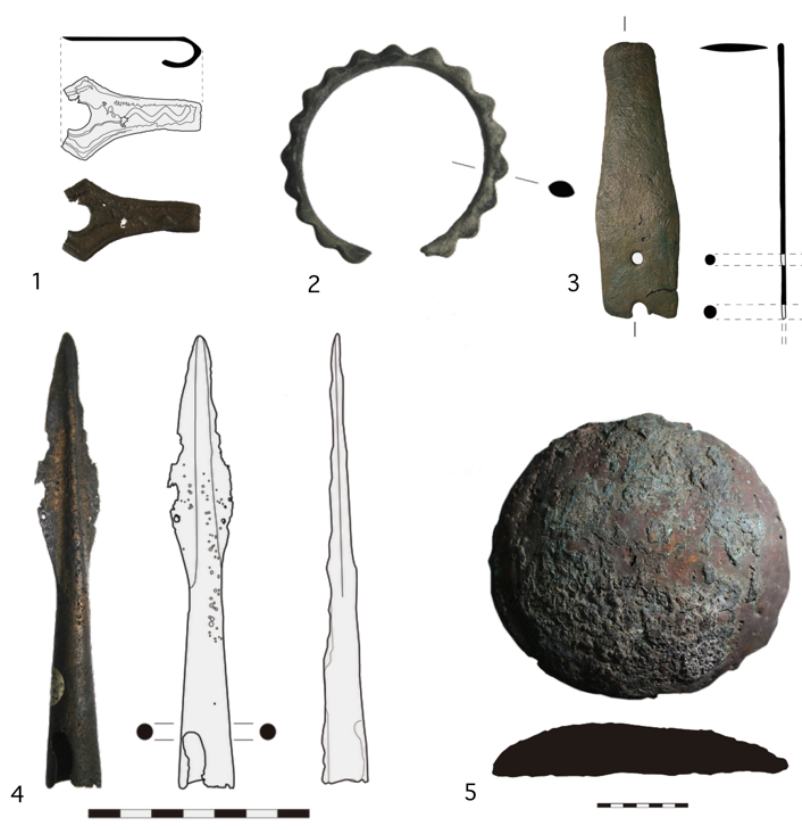

Figure 2. Example of most representative artefact's typology from the Rochelongue site. Ornaments (1 buckle belt and 2 bracelet); Weapons (3 sword and 4 spearhead) and semi-raw metal (5 copper ingot). (Source author).

The Launacien appellative applied to bronze hoards typically implied a recycling purpose linked to an indigenous culture of primarily continental inclination ${ }^{40}$. With the discovery of the underwater site at Rochelongue in 1964, the origin of

40 J.A.G. Dechelette, Manuel d'archéologie préhistorique celtique et gallo-romaine, Picard et fils, Paris 1908; J. Guilaine, L'âge du Bronze...; J.-P. Millotte, Le Jura et les plaines de Saône aux âges des métaux, Presses Univ. Franche-Comté, Besançon 1963; N.K. SANDARS, Bronze age cultures in France, Cambridge University Press, Cambridge 1957; O. TAFFanel, "Les civilisations pré-romaines dans la région de Mailhac, Aude", Etudes Roussillonnaises 5, 1956, 3-52. 
copper ingots in circulation and the destination of certain pieces found in this archaeological context were called into question ${ }^{41}$. Subsequently, a wider Mediterranean perspective started to emerge $^{42}$. The concentration of Launacien hoards in central and western Languedoc, between Mauguio and Corbières, should not negate the possible role played by these metal accumulations in the context of Mediterranean relations in the eighth and seventh centuries B.C. The idea of metal collections obtained by locals for trading with Etruscans was launched as a hypothesis without corresponding evidence ${ }^{43}$. In parallel, the presence of Etruscan, Greek and Phoenician ceramics, whether original or imitation, in indigenous funerary and habitation contexts preceding the foundation of Massalia leaves open the questions of chronology and impact of contact between the newcomers and local populations ${ }^{44}$. According to Dominique Garcia ${ }^{45}$ the Launacien deposits represent 'an original economic phenomenon that consisted of the development of indigenous metallurgic production for exchange purposes'. Currently, the term Launacien is used to identify the general cultural context of bronze hoards found from this era and composed of local products and foreign elements of Continental, Atlantic or Mediterranean origin. During the Archaic period, the so-called Launacien peoples of the west Languedoc coast experienced increasing contact with Mediterranean cultures from the east and

41 J. Guilaine, La France d'avant...

42 S. VERGER, Sur les chemins merveilleux des vierges byperboréennes: parures féminines septentrionales et circulations votives en Méditerranée à l'époque archaïque, Archéologies d'Orient et d'Occident et Sciences des textes, Paris 2005.

43 L. Long, Les épaves protohistoriques...; L. Long, P. Pomey, J.-C. Sourisseau, Les Étrusques en mer: épaves d'Antibes à Marseille, Édisud, Marseille 2002.

44 J. Guilaine, L. Carozza, D. Garcia, J. Gasco, T. Janin, B. Mille, Launac et le Launacien...

45 D. Garcia, "Épave de Rochelongue (Cap d'Agde)", Luc Long, Patrice Pomey, J.C. SourisseAu (eds), Les Étrusques en mer: épaves d'Antibes à Marseille, Édisud, Marseille 2002, 41.

"The Rochelongue underwater site and the coastal..." 
an influx of foreign products arriving by ship ${ }^{46}$. According to historical accounts, Phocaean Greeks established the colony of Massalia (Marseille) in 600 B.C., which greatly accelerated maritime trade and expanded cultural commingling across southern France and the surrounding regions ${ }^{47}$. More recently, some scholars however, have put forward contacts with Greek colonies in Sicily and southern Italy as a probable rationale to this metal circulation ${ }^{48}$.

\section{Rochelongue Underwater site. A reflection of coastal mobility.}

This section of the French coast close linked to Launacien offers good natural harbourages, especially in the estuaries, which allowed communication with the interior and access to its mineral resources-not only those close by, such as at Montaigne Noir and Cabriérès, but also those far distant, such as in Brittany. The region also sits strategically between Catalunya and Provence, with its ready access to northern Italy. These two intersections, combined with an accessible coast open to the Mediterranean, made this region a natural area for cross-cultural networking with a high range of cultural diversity ${ }^{49}$. An important number of shipwrecks have been found along this coast from a variety of

46 D. Garcia, J. VitaL, "Dynamiques culturelles de l'âge du Bronze et de l'âge du Fer dans le sud-est de la Gaule. Celtes et Gaulois", L'Archéologie face à l'Histoire 2, 2006, 6380 .

47 M. DieTLER, Archaeologies of colonialism: consumption, entanglement, and violence in ancient Mediterranean France. Berkeley: University of California Press 2010, 21.

48 S. Verger, L. Pernet, Une Odyssée gauloise...; S. Verger, Sur les chemins merveilleux des vierges byperboréennes: parures féminines septentrionales et circulations votives en Méditerranée à l'époque archaïque, Archéologies d'Orient et d'Occident et Sciences des textes, Paris 2005.

49 E. Gailledrat, Espaces coloniaux...; R. Graells, "De Italia al Bajo Aragón: la dinámica de intercambios indígena entre el s. vii y vi aC.”, Mobilité des hommes, diffusion des idées, circulation des biens dans l'espace européen à l'àge du Fer, Actes du XXVe Colloque de l'AFEAF, Bordeaux 2013, 727-736; J. GASCO, "Geographie regionale de l'age du bronze en Languedoc", Quaderns de prehistòria i arqueologia de Castelló 29, 2011, 135-151; J. Guilaine, G. RAnCOUle, "Les relations mediterran dennespre-coloniales et les debuts de l'Age du Fer languedocien. Les influences puniques en Languedoc occidental", Complutum 7, 1996, 125-140. 
chronology. The underwater site at Rochelongue was discovered in 1964 by André Bouscaras, a dedicated diver and shipwreck enthusiast responsible for locating many underwater sites (especially shipwrecks) in the waters of west Languedoc. The site was subjected to a number of archaeological investigations between 1964 and 1968, and again in $1970^{50}$. The underwater archaeological site is located on the Rochelongue reef off Cap d'Agde, geologically formed by a basaltic outcrop and medium size blocks. This basaltic geology is the result of a lava flow 740,000 years ago from the former Mount St. Loup volcano (Figure 3, feature 2). The reef runs southward and is surrounded by patches of Posidonia seagrass and sand. The reef extends into an area known as 'les mattes' and then splits into two branches. One branch turns to the east, towards the islet of Brescou, taking the form of a line of rocks bordering a large area of sand. The second branch heads westward for some $2 \mathrm{~km}$, in the direction of the mouth of the river Herault, before giving way to sand. The reef is most visible from shore in two areas: off the so-called Pointe de Notre Dame, some $400 \mathrm{~m}$ from the mouth of the Herault; and off the Pointe de Rochelongue, which directly faces the underwater site ${ }^{51}$. Water depth can change abruptly along this shore due to the topography of the seabed, and especially the reef. In some areas, the reef juts up abruptly more than $1.5 \mathrm{~m}$ from the bottom, which makes the area dangerous for coastal navigation. Ships passing these shores also are at risk of inclement weather.

\footnotetext{
50 J. Gasco, C. Tourette, G. Borja, “À propos du dépôt de bronze launacien de Rochelongue (Agde, Hérault)", Documents d'archéologie méridionale. Protohistoire du Sud de la France 35, 2014, 207-228.

51 G. Borja, C. Tourette, La Pointe de Rochelongue L'epave des bronzes' (Agde, hérault). DRASSM, Marseille 2011 (unpublished report); C. TOURETTE Étude de synthèse à la Pointe de Rochelongue, Agde (Hérault). DRASSM, Marseille 2006 (unpublished report).
}

"The Rochelongue underwater site and the coastal..." 


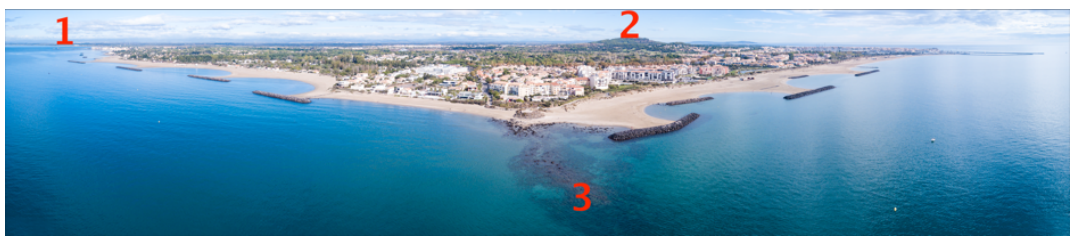

Figure 3. Panoramic view of Cap d'Agde, looking north: (1) Herault River mouth; (2) Saint-Loup Hill; and (3) Rochelongue reef (photograph by Javier Rodriguez).

As mentioned, interpretation of Rochelongue still in discussion $^{52}$, the idea of a shipwreck it is hard to proof because the absence of any wooden hull remains (even any trace of such), rope, rigging elements or other equipment typically associated with water craft that would provide definitive evidence of a boat or ship. The complete assemblage amounts to a total weight of approximately 1.3 tons, a rather low tonnage in comparison to that of known Mediterranean wrecks of the seventh and sixth centuries B.C., which range from 2-4 tons up to 30 tons. If indeed the site is that of a shipwreck, then the vessel type we most likely are dealing with is a small riverine boat with limited coastal capability, rather than a true sea-going ship. On the other hand the interpretation of the Rochelongue material as a votive offering has been argued mainly by Jean Gascó ${ }^{53}$, who has explained in depth the supplicatory nature of the deposit. This interpretation is in line with other sites that shows evidences of metallic artefacts submerged in the coastal or riverine environment and interpreted as votive. This is the case for sites dated in Bronze Age as the ones found at Great Britain (Samson 2006) or Spain (Priego 1995).

52 E. Aragón, "The Rochelongue Underwater site: (Re)assembling Contacts and Connectivity through a Multi-Methods Approach", A. Chołuj, M. Mileszczyk and K. Trusz (eds), Śtwiatowit Supplement Series U: Underwater Archaeology, Vol. I., Warsaw 2018, 39-62.

53 J. GASCO, "La céramique des cultures de l'extrême fin de l'âge du Bronze en Languedoc occidental", Documents d'archéologie méridionale. Protobistoire du Sud de la France $35,2012,127-150$. 
Although many scholars still are reluctant to accept this type of reading, at present it constitutes one of the principal alternatives to the shipwreck interpretation. Some obvious questions arise upon subscribing to the votive hypothesis: How and when did the deposition of all these objects happened? Does the assemblage represent one or several deposition episodes? How and why was the location selected? Were the objects thrown from a boat, or was the deposit the result of a wrecking (capsizing/swamping) event; alternatively, was the deposition made from a wooden platform or structure from shore? Was the deposit location marked in some way to ensure that subsequent deposition events would occur at the same spot? The distance from the site to the paleo-coast, even taking into account a $2 \mathrm{~m}$ rise in sea-level change, proposed for this coast ${ }^{54}$ still would have been about $500 \mathrm{~m}$, making the possibility that the material was deposited ritually (i.e., thrown) into the sea from land unlikely. In last instance any type of boat would be used for this ritual.

Whether one theory or another is accepted, we can affirm that both arguments fails not considering the skills of indigenous population in water transportation and marine practices in the surrounding coastal and fluvial landscape. Local societies of the LBA-EIA typically were embedded in riverine environments, as attested by the eighth-century B.C. settlement at La Motte (Agde), situated on the edge of a palaeo-bay near the mouth of the Herault River, but now submerged under the river ${ }^{55}$. Similarly, it is not coincidental that a large number of metal deposits appear in

\footnotetext{
54 P. Ambert, "Géologie et géomorphologie des pays de l'étang de Thau et de la basse vallée de l'Hérault. Agde et le Bassin de Thau”, M. Lugand, I. Bermond (eds.), Carte archéologique de la Gaule, Académie des Inscriptions et Belles-Lettres, Paris 2001, 48-57. 55 P.A. Moyat, Dumont, J.-F. Mariotti, T. Janin, S. Greck, L. Bouby, P. Ponel, P. VERDin, S. Verger, "Découverte d'un habitat et d'un dépôt métallique non funéraire du VIIIe s. av. J.-C. dans le lit de l'Hérault à Agde, sur le site de La Motte", Jahrbuch des Römisch-Germanischen Zentralmuseums Main₹ 54/1, 2010, 53-84; S. VERGER, A. DumONT, P. Moyat, B. Mille, "Le dépôt de bronzes du site fluvial de La Motte à Agde (Hérault)", Jabrbuch des Römisch-Germanischen Zentralmuseums 54, 2007, 85-171.
}

"The Rochelongue underwater site and the coastal..." 
close relation to watercourses ${ }^{56}$, especially given the notion in European Bronze Age cosmology of rivers as boundaries between different spheres or worlds ${ }^{57}$. In light of this, such communities almost certainly would have used watercraft for transport and trading along the network of rivers (and possibly the adjoining coastlines), utilising natural features within this environment for harbourages. Indigenous watercrafts are no infrequent in France where excavations at Sanguinet, Bordeaux, for example, have yielded at least nine specimens dated to the LBA/EIA ${ }^{58}$. Furthermore, the near 'invisibility' of prehistoric and proto-historic harbours (anthropogenic structures) in the archaeological record is easily explained. In her study of Late Bronze Age harbours in the Aegean, for which there are scant remains, Loizou ${ }^{59}$ argued that they must be viewed in the context of the dynamic seascape and considered as active cultural landscapes with socio-political implications. An analogous reading can be applied to the Rochelongue site located in a dynamic geographic and social space. The surrounding topography is full of natural markers (Figure 3): the rocky platform of Pointe Rochelongue, the Herault estuary to the west and the promontory of Cap d'Agde to the east; Mont Saint-Loup and the small islet of Brescou lying just off the coast ${ }^{60}$. All of

\footnotetext{
56 B. Dedet, G. Marchand, "Eau, arme et territoire aux Âges du Bronze final et du Fer en Languedoc et en Provence", Ausonius 1, 2015, 591-620; V. Ropiot, Peuplement et circulation dans les bassins fluviaux du Languedoc occidental, du Roussillon et de l'Ampourdan du IXe s. au début du IIe s. av. n. è, Université de Franche-Comté, Besançon 2007, 144.

57 C. HuTH, "Water between two worlds. Reflections on the explanatory value of archaeological finds in a Bronze Age river landscape", A. LEHOËRFF (ed.), Movement, exchange and identity in Europe in the 2nd and 1st millennia BC: beyond frontiers, Oxbow Books, Oxford-Philadelphia 2017, 277.

58 B. Dubos, "Les pirogues du lac de Sanguinet", Aquitania : revue interrégionale d'archéologie 22, 2006, 8-24.

59 E. Loizou, Late Bronze Age harbours in the Aegean. Towards another theoretical approach. Skyllis 2016, 16, 118-125.

60 J. Grimal, "Le mont Saint-Loup (AGDE, Hérault) et ses abords-Toponymie et archéologie", Los Rocaires 3, 2018, 2-11.
} 
these features would have served as navigational landmarks for riverine, coastal as well as terrestrial travel, and the estuary additionally would have offered shelter and points of debarkation for boats or ships.

Ultimately, and from a seascape perspective, the distinction between ritual and commercial activity may be a moot point, as 'people in traditional societies in coastal areas, as elsewhere, would not have separated ritual and habitual actions ${ }^{61}$. Thus, commercial dealings may have been consummated with ritual offerings or deposition representative of the materials being exchanged - in this case, raw and recycled metals on the one hand and metal handicraft works on the other. In this sense it can be argued that the assemblage of Rochelongue underwater site, it is representative of the coastal mobility of the indigenous populations of southern France in the transition of LBA-EIA in response to the increase presence of foreign Mediterranean cultures, marking the beginning new commercial dynamics.

It is not surprising that a society that traditionally lived by the coast or a river, as evidenced by the site of La Motte ${ }^{62}$, would develop a close relationship with its environment in terms of transportation, trade and exploitation of resources ${ }^{63}$. The Launecien metals following the course of the rivers and arriving to the coast as well as Rochelongue as argued before, seems to complete a circulation of materials between Catalonia and southwestern France that expand to southern Italy and even Greece $^{64}$ following the coast (Figure 4). Thus, the flow of

61 G. COONEY, "Introduction : seeing land from the sea", World Archaeology 35/3, 2004, 323-328.

62 P.A. Moyat, Dumont, J.-F. Mariotti, T. Janin, S. Greck, L. Bouby, P. Ponel, P. Verdin, S. Verger, "Découverte d'un hábitat...”; S. Verger, A. Dumont, P. Moyat, B. Mille, "Le dépôt de bronzes du site fluvial...".

63 R. GRAeLls, Las tumbas con importaciones...

64 R. Graells, "De Italia al Bajo...", 728; S. Verger "Des objets gaulois dans les sanctuaires archaïques de Grèce, de Sicile et d'Italie.", Comptes rendus des séances de

"The Rochelongue underwater site and the coastal..." 
materials and influences circulated bi-directionally between Italy and the Iberian Peninsula via southern France, which seems to have acted as a bridge between the two regions ${ }^{65}$.

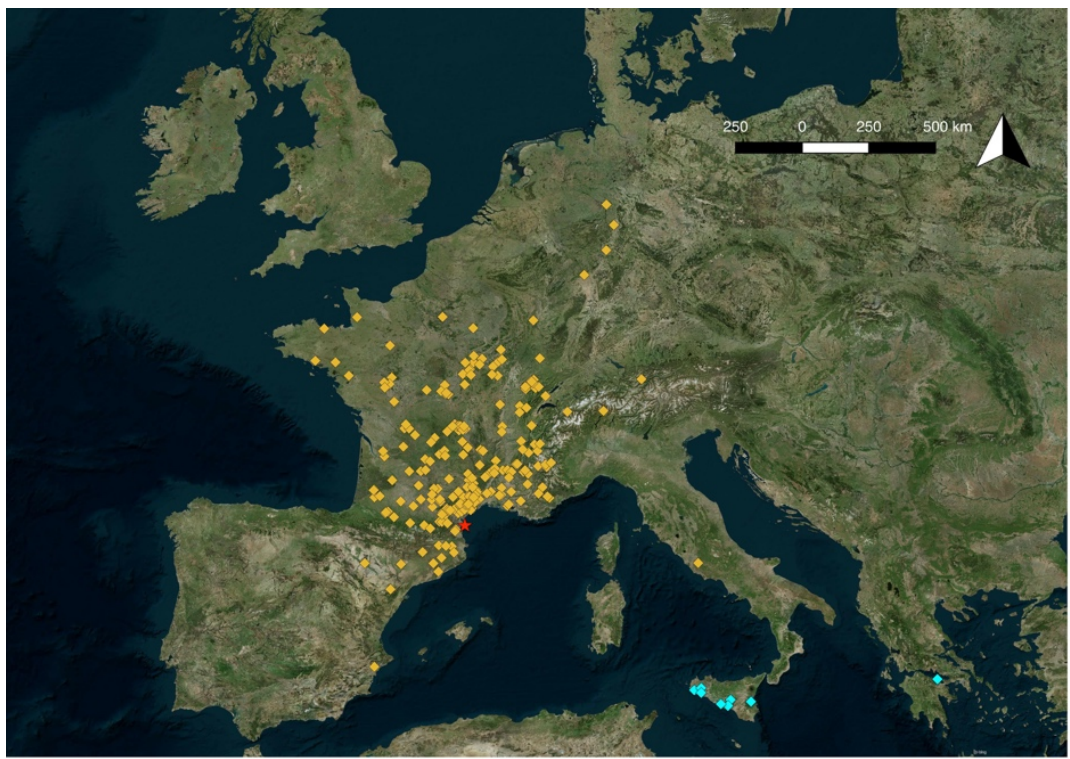

Figure 4. Locations of other archaeological sites where Launacien artefact types represented in the Rochelongue assemblage (Red star) have been found. Cian marks indicates Greek context (map by author, based on data from Guilaine et al. 2017).

\section{Conclusion.}

Maritime activity in the western Mediterranean experienced significant growth from the late eighth through to the sixth centuries B.C. This growth impacted the mobility of various agents, both local and foreign, and resulted in direct interactions

l'Académie des Inscriptions et Belles-Lettres 147/1, 2003, 525-573; S. Verger, L. PERnET, Une Odyssée gauloise...

65 R. GraelLs, "De Italia al Bajo...”, 733. 
between disparate cultures and subsequent social, economic and cultural upheavals. The underwater archaeological site of Rochelongue, discussed in this paper produced a unique material assemblage from this period. Dated to the end of the seventh or first quarter of the sixth centuries B.C., the site reveals a short, but relevant, episode provides an opportunity to analyse the capacity of mobility of local agents in collecting and moving metal goods across the rivers and the coast to service foreign demands. It is representative of a possible framework of local groups to organise or even guarantee the material conditions for exchange, and furthermore a necessary engagement with existing exchange networks. This interpretative vision of the Rochelongue site provides a fresh perspective for future studies on the nautical capabilities of indigenous populations before and after the arrival of seafaring eastern Mediterranean cultures.

Acknowledgement.

I am grateful to Lazaro Lagostena, Wendy van Duivenvoorde, Mark Polzer, Ignacio Montero and Amy Roberts and the editors and anonymous reviewers for helpful discussions and comments on the text. I also wish to thank the institutions that made possible this research; namely, Flinders University in Australia, the University of Cadiz in Spain and DRASSM in France.

"The Rochelongue underwater site and the coastal..." 


\section{Bibliography}

P. AMBERT, "Géologie et géomorphologie des pays de l'étang de Thau et de la basse vallée de l'Hérault. Agde et le Bassin de Thau", M. LugAnd, I. BERMOND (eds), Carte archéologique de la Gaule, Académie des Inscriptions et Belles-Lettres, Paris 2001, 48-57

E. ARAGON, "The Rochelongue Underwater site: (Re)assembling Contacts and Connectivity through a Multi-Methods Approach", A. Choluj, M. MileszCZYK, K. TRUSZ (eds.), Śtwiatowit Supplement Series U: Underwater Archaeology, Vol. I., Warsaw 2018, 39-62

A. BARbot, Les Épaves Archaïques en la Méditerranée Occidentale, Paris Pantheon Sorbonne, Unpublished Master thesis, Mémoire de maittrise Paris I, Paris 2000

G. Borja, C, TOurette, La Pointe de Rochelongue L'epave des bronzes' (Agde, hérault), DRASSM, Marseille 2011 (unpublished report)

P. CAZAlis DE FONDOUCE, "La cachette de fondeur de Launac", Mémoires de la Société Archéologique de Montpellier 2, 1900, 171-208

G. COONEY, "Introduction: seeing land from the sea", World Archaeology 35/3, 2004, 323-328

B. Dedet, G. MARChAnd, "Eau, arme et territoire aux Âges du Bronze final et du Fer en Languedoc et en Provence", Ausonius 1, 2015, 591-620

J.A.G. DeChelETTE, Manuel d'archéologie préhistorique celtique et galloromaine, Picard et fils, Paris 1908

B. Devillers, G. Bony, J.-P. Degeai, J. Gascó, T. Lachenal, H. Bruneton, F. Yung, H. Oueslati and A. Thierry, "Holocene coastal environmental changes and human occupation of the lower Hérault River, southern France”, Quaternary Science Reviews 222/1, 2019

M. DIETLER, Archaeologies of colonialism: consumption, entanglement, and violence in ancient Mediterranean France. Berkeley: University of California Press 2010 
B. Dubos, "Les pirogues du lac de Sanguinet", Aquitania: revue interrégionale d'archéologie 22, 2006, 7-53

M.I. FINLEY, The ancient economy, University of California Press, Los Angeles 1973

E. GAILLEDRAT, "Tierra, fuego y agua: poder y sociedad entre el Ródano y los Pirineos durante la primera Edad del Hierro", M.C. BELARTE, D. GARCIA, J. SANMARTÍ (eds.), Les estructures socials protohistóriques a la Gàllia i a Ibèria, Calafell: Arqueo Mediterrània, 2013, 97-118

E. GAILLEDRAT, Espaces coloniaux et indigènes sur les rivages d'ExtrêmeOccident méditerranéen (Xe-IIIe s. avant notre ère), Pulm, Montpellier 2014

D. GARCIA, Entre Ibères et Ligures: Lodévois et moyenne vallée de l'Hérault protohistoriques, CNRS Éditions, Paris 1993

D. GARCiA, "Épave de Rochelongue (Cap d'Agde)", LUC LONG, PATRICE POMEY, J.-C. SOURISSEAU (eds.), Les Étrusques en mer: épaves d'Antibes à Marseille, Édisud, Marseille 2002, 38-41

D. GARCIA, La Celtique méditerranéenne: Habitats et sociétés en Languedoc et en Provence du VIIIe au IIe siècle avant JC., Editions Errance, Paris 2004

D. GARCIA, J. VITAL, "Dynamiques culturelles de l'âge du Bronze et de l'âge du Fer dans le sud-est de la Gaule. Celtes et Gaulois", L'Archéologie face à l'Histoire 2, 2006, 63-80

J. GASCO, "Geographie regionale de l'age du bronze en Languedoc", Quaderns de prehistòria i arqueologia de Castelló 29, 2011, 135-151

J. GASCO, "La céramique des cultures de l'extrême fin de l'âge du Bronze en Languedoc occidental", Documents d'archéologie méridionale. Protohistoire du Sud de la France 35, 2012, 127-150

J. Gasco, C. TouretTe, G. BorJA, "À propos du dépôt de bronze launacien de Rochelongue (Agde, Hérault)", Documents d'archéologie méridionale. Protohistoire du Sud de la France 35, 2014, 207-228

J. GIRY, "La nécropole préromaine de St-Julien (Cne de Pézenas, Hérault)", Rivista di Studi Liguri 31, 1965, 117-235

"The Rochelongue underwater site and the coastal..." 
A. Gorgues, "Trade in a liminal zone. Commercial encounter and transformation in the Iron Age North West Mediterranean", I. ARMIT, P. Hrvoje, M. Cresnar, P. MAson, L. Büster (eds.), Cultural Encounters in Later Prehistoric Europe, Budapest 2016, 167-210

R. GRAELLS, Las tumbas con importaciones y la recepción del Mediterráneo en el nordeste de la Península Ibérica (siglos VII-VI a.C), Departamento de Arqueologia, Universitat de Lleida, Lleida 2010

R. GRAELLS, "De Italia al Bajo Aragón: la dinámica de intercambios indígena entre el s. vii y vi aC.", Mobilité des hommes, diffusion des idées, circulation des biens dans l'espace européen à l'àge du Fer, Actes du XXVe Colloque de l'AFE AF, Bordeaux 2013, 727-736

R. GRAELlS, S. SARDÀ, "Entre carneros, palomas y ciervos: la asimilación de estimulos mediterráneos a través de la Toréutica. El ejemplo del noreste de la Península ibérica durante el s. VI aC.", Rivista di Studi Liguri 71, 2007, 5-28

M. GRAS, "Avant les réseaux. Les stratigraphies conceptuelles de la Méditerranée archaïque", L. CAPDETREY, J. ZuRBACH (eds.), Mobilités grecques. Mowvements, réseaux, contacts en Méditerranée, de l'époque archä̈que à l'époque hellénistique, De Boccard, Bourdeaux 2012, 13-24

J. Grimal, "Le mont Saint-Loup (AGDE, Hérault) et ses abordsToponymie et archéologie", Los Rocaires 3, 2018, 2-11

J. Guilaine, L'âge du Bronze en Languedoc occidental, Roussillon, Ariège, Klincksieck, Paris 1972

J. Guilaine, La France d'avant la France: du Néolithique à l'Âge du Fer, Hachette Littératures, Paris 1980

J. Guilaine, L. Carozza, D. Garcia, J. Gasco, T. Janin, B. Mille, Launac et le Launacien. Dépôts de bronżes protohistoriques du sud de la Gaule, Presses Universitaires de la Méditerranée, Montpellier 2017

J. Guilaine, G. RANCOUlE, "Les relations mediterran dennesprecoloniales et les debuts de l'Age du Fer languedocien. Les influences puniques en Languedoc occidental", Complutum 7, 1996, 125-140

P. Horden, N. Purcell, The corrupting sea: a study of Mediterranean history, Wiley-Blackwell, Oxford 2000 
C. Hugues, "La découverte sous-marine de Rochelongue, Agde (Hérault)", Comptes-rendus des séances de l'année. Académie des inscriptions et belles-lettres 109/1, 1965, 176-178

C. HUTH, "Water between two worlds. Reflections on the explanatory value of archaeological finds in a Bronze Age river landscape", A. LEHOËRFF (ed.), Movement, exchange and identity in Europe in the $2 n d$ and 1 st millennia BC: beyond frontiers, Oxbow Books, Oxford-Philadelphia 2017, 276-289

T. JANIN, "L'évolution du Bronze final IIIB et la transition Bronze-Fer en Languedoc occidental d'après la culture matérielle des nécropoles", Documents d'archéologie méridionale 15/1, 1992, 243-259

S. JUNGHANS, E. SANGMEISTER, M. SCHRÖDER, Kupfer und Bronze in der friben Metallzeit Europas 4, Gebr.Mann, Berlin 1974

A.B. KNAPP, S. DEMESTICHA, Mediterranean connections: maritime transport containers and seaborne trade in the Bronze and Early Iron Age, Taylor \& Francis, New York 2016

J. LEIDWANGER, "Modeling distance with time in ancient Mediterranean seafaring: a GIS application for the interpretation of maritime connectivity", Journal of Archaeological Science 40/8, 2013, 33023308

S. LENORZER, "Pratiques funéraires du Bronze final IIIb au premier âge du Fer en Languedoc occidental et Midi-Pyrénées: approche archéo-anthropologique des nécropoles à incinération", Bulletin de la Société prébistorique française 103/3, 2006, 622-625

F. LEROY, L. BOUBY, F. GUIBAL, Les gisements protohistoriques de l'étang de Thau (Hérault). Temps et espaces culturels du VTe au IIe millénaire en France du Sud, IVe Rencontres Méridionales de Préhistoire Récente, Association pour le développement de l'archeologie en Languedoc-Rousillon, Nîmes 2000

C. LlinAs, A. ROBERT, "La nécropole de Saint-Julien à Pézenas. Fouilles 1969-1970", Revue archéologique de Narbonnaise 4/1, 1971, 1-29

L. LONG, Les épaves protohistoriques de la côte gauloise et de la Corse:(Vle-IIIe siècles avant J.C.). La circulació d'àmfores al Mediterrani occidental durant la Protohistòria (segles VIII-III aC): aspectes quantitatius $i$ anàlisi de continguts,

"The Rochelongue underwater site and the coastal..." 
Departament de Prehistòria, Història Antiga i Arqueologia, Calafell 2004

L. LONG, P. POMEY, J.-C. SOURISSEAU, Les Étrusques en mer: épaves d'Antibes à Marseille, Édisud, Marseille 2002

E. LoIzou, "Late Bronze Age harbours in the Aegean. Towards another theoretical approach", Skyllis 16, 2016, 118-125

J.-P. MillotTe, Le Jura et les plaines de Saône aux âges des métaux, Presses Univ. Franche-Comté, Besançon 1963

C. MOATTI, "Mobilités et circulations: approches historiographique et conceptuelle", Mobilités grecques. Mouvements, réseaux, contacts en Méditerranée, de l'époque archaïque à l'époque hellénistique 46, 2012, 39-54

J.-P. MOREL, "Les relations économiques dans l'Occident grec", Publications de l'École française de Rome 67/1, 1983, 549-580

P.A. Moyat, Dumont, J.-F. MARiotti, T. JANin, S. Greck, L. Bouby, P. Ponel, P. Verdin, S. Verger, "Découverte d'un habitat et d'un dépôt métallique non funéraire du VIIIe s. av. J.-C. dans le lit de l'Hérault à Agde, sur le site de La Motte", Jahrbuch des RömischGermanischen Zentralmuseums Mainz 54/1, 2010, 53-84

A. NICKELS, "Essai sur le développement topographique de la nécropole protohistorique de Pézenas (Hérault)", Gallia 47, 1990, 1-27

A. Nickels, G. Marchand, M. Schwaller, H. Duday, P. ColumeAu, "Agde, la nécropole du premier Âge du Fer", Revue Archéologique de Narbonnaise. Suppléments 19, 1980, 1-499

R. OSBORNE, "The potential mobility of human populations", Oxford Journal of Archaeology 10/2, 1991, 231-252

M.R.G. PRIEGO, Ritos de paso y puntos de paso: La Ría de Huelva en el mundo del Bronce Final Europeo, Editorial Complutense, Madrid 1995

M. PY, Les gaulois du Midi. De la fin de l'âge du Bronze à la conquête romaine, la memoire du temps, Hachette, Paris 1993

V. Ropiot, Peuplement et circulation dans les bassins fluviaux du Languedoc occidental, du Roussillon et de l'Ampourdan du IXe s. au début du IIe s. av. n. è, Université de Franche-Comté, Besançon 2007 
A.V. SAMSON, "Offshore finds from the Bronze Age in North-Western Europe: the shipwreck scenario revisited", Oxford Journal of Archaeology 25/4, 2006, 371-388

N.K. SANDARS, Bronze age cultures in France, Cambridge University Press, Cambridge 1957

O. TAFFANEL, "Les civilisations pré-romaines dans la région de Mailhac, Aude", Etudes Roussillonnaises 5, 1956, 3-52

O. TAFfanel, J. TAFFAnel, "Deux tombes de cavaliers du Ier Âge du Fer à Mailhac (Aude)", Gallia 20/1, 1962, 3-32

C. TOuretTe, Étude de synthèse à la Pointe de Rochelongue, Agde (Hérault), DRASSM, Marseille 2006 (unpublished report)

D. UGolinI, L'identité face au commerce: exemples languedociens. Contacts et acculturations en Méditerranée occidentale: hommages à Michel Bats, Éditions Errance, Centre Camille Jullian, Hyères-les-Palmiers 2018

P. VAN DOMmelen, "Colonialism and Migration in the Ancient Mediterranean", Annual Review of Anthropology 41, 2012, 393-409

S. VERGER, "Des objets gaulois dans les sanctuaires archaïques de

Grèce, de Sicile et d'Italie", Comptes rendus des séances de l'Académie des Inscriptions et Belles-Lettres 147/1, 2003, 525-573

S. VERGER, Sur les chemins merveilleux des vierges byperboréennes: parures féminines septentrionales et circulations votives en Méditerranée à l'époque archaïque, Archéologies d'Orient et d'Occident et Sciences des textes, Paris 2005

S. Verger, A. Dumont, P. Moyat, B. Mille, "Le dépôt de bronzes du site fluvial de La Motte à Agde (Hérault)", Jahrbuch des Römisch-Germanischen Zentralmuseums 54, 2007, 85-171

S. VERGER, L. PERNET, Une Odyssée gauloise: parures de femmes à l'origine des premiers échanges entre la Grèce et la Gaule, Éditions Errance, Montpellier 2013

J. VIVES-FERRÁNDIZ, "Mediterranean Networks and material connections: a view from eastern Iberia and The Balearic Islands (12th8th Centuries BC)", A. BABBI (ed.), The Mediterranean Mirror: Cultural

"The Rochelongue underwater site and the coastal..." 
RIPARIA VOL. 6 (2020)

Contacts in the Mediterranean Sea Between 1200 and 750 BC. Schnell \& Steiner GmbH., Verlag des Römisch-Germanischen Zentralmuseums, Mainz 2015, 161-175 